\section{Abstract}

Australia's bushfire seasons are expected to become longer and more severe due to the effects of climate change and an increasing population living in rural-urban fringes. Social and economic vulnerability to extreme natural hazards means that Australia's emergency services sector plays a significant role in community safety and wellbeing. Therefore, it is important that the sector continually improves. Australia has a long history of conducting external reviews into significant bushfires. While these reviews receive good support and seek to identify relevant lessons, barriers remain that prevent these lessons from being effectively learnt. It is possible that some of these barriers exist because the stratum of work impedes the capture, codifying and adjustments to systems. This research investigated the premise that lessons learnt in the Australian emergency services sector occurs on a stratum, with different types of lessons learnt at different levels of work. Four significant independent bushfire reviews were analysed to evaluate whether specific lessons could be aligned to the stratum of work. Findings were that not all lessons apply to all levels of organisations. This supports the premise that lessons are learnt on a vertical organisational stratum; for example, some lessons were operational, others were tactical and some were strategic. It was determined that a lack of understanding of the barriers within an organisations stratum could impede the effectiveness of lessons being learnt.

\title{
The efficacy of aligning lessons learnt from significant bushfire incidents to the organisational stratum
}

Peer Reviewed

Jennifer Medbury ${ }^{1}$

David J. Brooks ${ }^{1}$

Michael Coole ${ }^{1}$

1 Edith Cowan University, Perth, Western Australia.

\section{SUBMITTED}

25 July 2020

\section{ACCEPTED}

1 December 2020

\section{DOI}

www.doi.org/10.47389/36.2.26
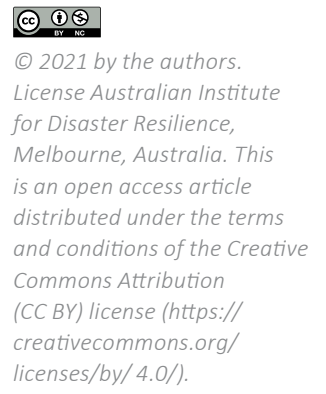

\section{Introduction}

Australia's bushfire seasons are lasting longer and getting more severe. More Australians are living in rural-urban fringe areas and Australia's climate has changed with increasing temperatures (CSIRO \& Bureau of Meteorology 2018). These circumstances present challenges for the emergency services sector, which includes multiple organisations (each with several organisational strata) operating in a high stress, highconsequence environment. The emergency services sector needs to be continually improving, which requires effective lessons learnt processes to prevent, prepare, respond to and recover from bushfires.

External inquiries are conducted after significant disasters, especially bushfires (Dufty 2013; Owen et al. 2018).

According to Eburn and Dovers (2015, p.501) 'between 1939 and 2010 Royal Commissions and other inquiries have produced 953 recommendations as lessons to reduce the risk of bushfire'. Such reviews are conducted by experts, have clear terms of reference and state the methodology, which includes consultation with experts and/or affected community members. For example, both the Margaret River bushfire review (Keelty 2012) and the Bega Valley Fires Independent Review (Keelty 2018) were authored by Michael Joseph Keelty AO APM, a former Commissioner of the Australian Federal Police. Other reviews, such as the review into the 2009 Victorian bushfires (Teague, McLeod \& Pascoe 2010), are conducted as royal commissions, which carries significant weight (Australian Law Reform Commission 2010).

Nevertheless, questions arise regarding whether the recommendations identified in reviews are actually converted to lessons, or even learnt by the emergency services sector and the Australian community (Dufty 2013, Owen et al. 2018) and integrated into capability. Reasons for such criticism include limited follow-up after the event and whether lessons can be transferred between events (Eburn \& Dovers 2015). There is also no existing standard for 
conducting external reviews (Cole et al. 2018, Dufty 2013, Owen et al. 2018) and variances exist in codifying and communicating lessons learnt.

Noting the literature limitations, this study considered the research question: 'Do the lessons identified in prior significant incidents support the proposition that lessons are learnt at different stratum of the organisation?'

\section{Learning in the emergency services sector}

There is an extensive body of knowledge about emergency services, emergency management and disaster management (Howes et al. 2015; Owen et al. 2018; Whitmer, LaGoy \& Sims 2018; Glassey 2015). This literature covers the 4 stages of the emergency management cycle being prevention, preparedness, response and recovery. There is a significant emphasis on future risk factors such as the effects of climate change (McAneney, Chen \& Pitman 2009; McCaw 2013; Winkworth et al. 2009). A subset of the literature focuses on significant Australian bushfires, especially the 1983 Ash Wednesday bushfires and the 2009 Victorian bushfires (Cameron et al. 2009, Leonard \& Howitt 2010, Valent 1984).

\section{How organisations learn}

Organisations adapt and learn and this results in tangible and intangible benefits (Deverell 2009 Duffield \& Whitty 2015, Rowe \& Sikes 2006). However, the structure of an organisation can affect its ability to learn (Aubry \& Lavoie-Tremblay 2018). This supports the work of Garvin, Edmondson and Gino (2008), who argue that concrete learning processes and leadership that reinforces learning are important factors in establishing a learning organisation. This is particularly relevant for emergency services organisations that are 'traditionally hierarchical in nature and tend to value their own command and control arrangements' (Owen et al. 2018, p.716). For example, Boin and t'Hart (2010) argue that there are different challenges at the operational and strategic level in emergency services organisations.

\section{Gaps in emergency services learning}

There is a large body of knowledge about identifying and learning lessons, also known as lessons management, in emergency management (Cole et al. 2018, Jackson 2016, Stuart \& Thomason 2018, Donahue \& Tuohy 2006). A review of this work showed some dissent in organisational learning literature regarding the use of the terms 'lessons learnt' and 'lessons management'. However, the definition differences of these terms are outside the scope of this paper. Within the Australian context, a seminal text is the Lessons Management Handbook (Australian Institute for Disaster Resilience 2019), which includes a 4-step cycle for managing lessons. These are:

collection

- analysis

- implementation

- monitoring and review.
As Owen and co-authors (2018) argue, this body of knowledge is growing, stating that:

a search of one database, for example (Proquest) revealed that of the 266 publications identified using the search terms learning lessons and emergency management 50 per cent of them had been published in the past five years.

(Owen et al. 2018, p.716).

Cole and co-authors (2018, p.34) conducted a meta-analysis of '1,336 recommendations made in 55 Australian major postevent reviews and inquiries since 2009'. Although this research identified common themes across the post-event reviews, these themes were not aligned to specific organisational strata and failed to consider Boin and t'Hart's (2010) views about the challenges for learning lessons at different levels in emergency services organisations. This limitation indicates that a gap in the literature exists. Although literature about Stratified Systems Theory, organisational learning and learning in the emergency services sector already exists, to date, these have not been fused to investigate the lessons-learnt process in different strata in emergency services organisations.

\section{Underlying theory}

The idea of different strata existing within an organisation containing different roles, responsibilities and outlook based on task abstraction can be traced back to the work of Jaques (1996, 2016). Stratified Systems Theory states that organisations have multiple levels, or strata, based on the time span of control (Table 1). Time span of control is a measurement of 'the target completion time of the longest task, project, or program assigned to that role' (Jaques 1990). Jaques (1996) identified 7 strata within an organisation:

$$
\begin{aligned}
& \text { - } \text { front-line } \\
& \text { - } \text { first-line manager } \\
& \text { - } \text { unit manager } \\
& \text { - } \text { general manager } \\
& \text { - } \text { vice president } \\
& \text { - } \text { chief executive officer. }
\end{aligned}
$$

Stratified Systems Theory is a robust means of evaluating organisations and allows for comparisons between different organisations (Craddock 2009). Therefore, this theory has direct relevance to the lessons-learnt process in the emergency services sector as disasters usually involve a multi-agency response. For example, Jaques (2016) highlights how each organisation's stratum aligns with other orgaisation's strata; where indiviuals from one stratum may have responsibility for the activities of members of another organisational stratum, but with no line management authority. 
Table 1. Occupational stratum of work in organisations (Jaques 1996, 2002).

\begin{tabular}{|c|c|c|c|}
\hline Stratum & $\begin{array}{l}\text { Time span of } \\
\text { discretion }\end{array}$ & Role complexity & Role \\
\hline 7 & $20+$ years & $\begin{array}{l}\text { Extrapolative } \\
\text { development of } \\
\text { whole systems }\end{array}$ & CEO \\
\hline 6 & 10 to 20 years & $\begin{array}{l}\text { Defining whole } \\
\text { systems }\end{array}$ & $\begin{array}{l}\text { Executive } \\
\text { Vice } \\
\text { President }\end{array}$ \\
\hline 5 & 5 to 10 years & $\begin{array}{l}\text { Shaping whole } \\
\text { systems }\end{array}$ & $\begin{array}{l}\text { Business Unit } \\
\text { President }\end{array}$ \\
\hline 4 & 2 to 5 years & $\begin{array}{l}\text { Transforming } \\
\text { systems }\end{array}$ & $\begin{array}{l}\text { General } \\
\text { Manager }\end{array}$ \\
\hline 3 & 1 to 2 years & Task extrapolation & $\begin{array}{l}\text { Unit } \\
\text { Manager }\end{array}$ \\
\hline 2 & $\begin{array}{l}3 \text { months to } 1 \\
\text { year }\end{array}$ & Task definition & $\begin{array}{l}\text { First-line } \\
\text { Manager }\end{array}$ \\
\hline 1 & $\begin{array}{l}1 \text { day to } 3 \\
\text { months }\end{array}$ & Concrete shaping & $\begin{array}{l}\text { Front-line } \\
\text { workers }\end{array}$ \\
\hline
\end{tabular}

\section{Methodology}

This study applied a 2-stage design that, while acknowledging the theoretical framing of Jaques's work, compressed the stratum of work to 3 levels. Using this revised stratum, significant bushfire events in Australia were thematically analysed.

\section{Stage 1: Compressing Jaques's stratum of work}

Jaques (1996) Stratified Systems Theory can be used to classify organisational positions into 7 different strata. However, it is difficult to consistently apply the full Stratified Systems Theory model to every organisation as the reviews focused on the bushfire incident rather than on the organisations. Therefore, the Stratified Systems Theory needed to be compressed into 3 levels that were grouped based on alignment to the generally used strata designations of operational (front-line), tactical (middle managers) and strategic (executives).

\section{Stage 2: Content and thematic analysis}

The most appropriate method for addressing the research questions involved purposeful sampling and thematic analysis (Braun \& Clarke 2006). As a methodological process, purposeful sampling involves selecting participants, or relevant documents, 'directly related to the central phenomenon or key concept being explored in a study' (Creswell \& Plano Clark 2018, p.176). For this study, purposive sampling enabled the selection of informationrich cases that represent the complex elements of lessons learnt from bushfire emergencies, and specifically, investigating the link between lessons and the stratum of work.

\section{Analysis}

This study investigated lessons identified within the bushfirethreat environment across 4 external reviews of significant bushfires that occurred in Australia between 1983 and 2018. The study followed the iterative thematic analysis process outlined by Braun and Clarke (2006). This method involved reviewing the data, generating a code list and undertaking multiple rounds of searching, extracting and reviewing themes. Selecting external post-event reviews that were conducted by experts and included a methodology section provided validity to the study as it indicates that the data is credible (Leung 2015). The iterative thematic analysis process and using multiple sources to extract themes (triangulation process) also added to the reliability and validity of the study (Creswell \& Plano Clark 2018).

\section{Stage 1: Compressing Jaques's stratum of work}

The Stratified Systems Theory was compressed to 3 levels of operational, middle management and executive as detailed in Table 2.

Table 2: Compressed stratum of works.

\begin{tabular}{lll}
$\begin{array}{l}\text { Jacques's } \\
\text { strata }\end{array}$ & $\begin{array}{l}\text { Compressed } \\
\text { strata }\end{array}$ & Description \\
\hline 7 to 8 & $\begin{array}{l}\text { 3. Strategic } \\
\text { executive }\end{array}$ & $\begin{array}{l}\text { Strategic decision-makers (i.e. } \\
\text { senior leaders and government } \\
\text { ministers, develops policies, } \\
\text { allocates agency resources). }\end{array}$ \\
\hline 4 to 6 & $\begin{array}{l}\text { 2. Tactical } \\
\text { middle }\end{array}$ & $\begin{array}{l}\text { Operational decision-makers (i.e. } \\
\text { team/section leaders, implement } \\
\text { policy, allocates tactical/daily } \\
\text { resources). }\end{array}$ \\
\hline 1 to 3 & 1. Operational & $\begin{array}{l}\text { Tactical-level decision-makers } \\
\text { (i.e. first responders, direct } \\
\text { interaction with the public). }\end{array}$ \\
\hline
\end{tabular}

\section{Stage 2: Thematic analysis}

Table 3 presents the inclusion criteria for the published documents of post-event reviews of Australian bushfires (Benoot et al. 2016, Eburn \& Dovers 2015).

Table 3: Inclusion criteria.

\begin{tabular}{lll}
\hline Review type & Availability & Methodology \\
\hline Royal Commission & $\begin{array}{l}\text { Publicly } \\
\text { available }\end{array}$ & $\begin{array}{l}\text { Publicly } \\
\text { available }\end{array}$ \\
OR & & \\
Parliamentary Inquiry & & \\
OR & \\
Inquiry under existing \\
legislation \\
OR \\
Independent Review
\end{tabular}


Using this process, 4 reviews of significant bushfire incidents were selected:

- 1983 Ash Wednesday bushfire review (Miller, Carter \& Stephens 1984)

- 2009 Victorian bushfire review (Teague et al. 2010)

- 2011 Margaret River bushfire review (Keelty 2012)

- 2018 Bega Valley bushfire review (Keelty 2018).

The 4 reviewed documents totalled 399 pages, which were coded for analysis. A code list was developed and refined throughout an iterative coding process so that analysis of each document was consistent. Each code related to a specific type of lesson. Lessons were defined as a specific finding and/or recommendation that can be actioned in the future (either to repeat in the future or change in the future). As each lesson was extracted, it was mapped against the established compressed stratum of work.

\section{Ash Wednesday bushfire review}

On 16 February 1983, 180 bushfires were burning across Victoria. These fires had a catastrophic impact on the communities affected with 47 people killed, 2080 homes damaged or destroyed and approximately 200,000 hectares burnt (Miller et al. 1984, p.23). The subsequent review covered all phases of the emergency management cycle. Although the review did not use the specific terminology of 'organisational strata', there were statements about the importance of senior and experienced officers helping junior officers and how decisions were delegated from the state-level Country Fire Authority to regional (local) levels. Another key lesson, which primarily aligns to the executive and operational strata, was that legislation, policies and procedures should be enhanced to prepare, prevent and respond to bushfire hazards and to recovery from bushfire incidents. For example, the review stated that 'suitable legislation would enable the State Government to declare a "State of Emergency" or "State of Disaster"...' (Miller et al. 1984, p.63).

The review added that the Country Fire Authority and Forests Commission Victoria should not be merged into one organisation and should not adopt a common communications system. Instead, the focus should be increased liaison and coordination. The review's emphasis on communication and coordination included agencies that are not primarily focused on disaster situations and members of the public. Although these lessons are largely aligned to the executive strata (those responsible for establishing and shaping organisational culture), there are relevant lessons for the middle management and operational strata that conduct the liaison activities.

\section{Victorian bushfire review}

On 7 February 2009 (Black Saturday), over 300 bushfires burned in Victoria. 173 people died and an estimated \$4 billion in damage occurred (Teague et al. 2010). Unlike the other reviews, the review into these fires was established as a Royal Commission. Although the commission's final report referred to other inquiries, including the 1998 Linton Inquiry that reviewed incidents relating to the death of 5 firefighters, the report did not reference the 1983 Ash Wednesday review that related to the same geographic area.

The review included the 4 phases of the emergency management cycle. The report did not use the specific terminology of 'organisational strata' but did consider organisational-level change and had specific recommendations for senior executives. For example, the review recommended appointing a full-time fire commissioner, increasing prescribed burning and that 'Victoria's ageing electricity infrastructure requires updating' (Teague et al. 2010, p.12). There were lessons identified that related to information flow and information management. This information lessons included having more nuanced bushfire warnings and more specific information to operational firefighters. The lesson about the nuanced bushfire warning can be aligned to the middle management strata that prepares the community education programs and the operational strata that provides advice to the public.

\section{Margaret River bushfire review}

The 2011 Margaret River bushfires in Western Australia started when 2 prescribed burns became uncontrolled. They resulted in 139 people being displaced; 32 homes, 9 chalets and 4 sheds being destroyed and 3400 hectares burnt (Keelty 2012). The primary focus of the review was to analyse how the Western Australia Department of Environment and Conservation planned and managed the 2 prescribed burns. The review did not specifically refer to different strata within the department but did use terms such as 'middle management'.

The review covered 3 phases of the emergency management cycle: prevention, preparedness and response. The review referred to other reviews including the 2010 Ferguson Review (Ferguson 2010), which focused on the department's ability to manage fires and a Western Australia Supreme Court decision about prescribed burning. A key lesson in the review was that managing the risks of prescribed burns, especially in the rural-urban fringe, is complicated because not conducting prescribed burns can lead to catastrophic situations if a bushfire occurs. Although aspects of these lessons can be aligned to the operational strata, which includes the individuals and teams who conduct prescribed burns, the middle management stratum was specifically mentioned. There are also lessons that can be aligned to the executive strata that is responsible for setting the risk assessment process, which was considered by the review to be out-of-date and inconsistently applied.

\section{Bega Valley bushfire review}

On 18 March 2018, multiple bushfires destroyed 65 homes, 70 caravans and cabins and 1250 hectares in the Bega Valley in New South Wales. The review focused on one phase of the emergency management cycle: response. The review assessed the relationship between Fire and Rescue New South Wales (FRNSW) and the Rural Fire Service (RFS). For example, the review stated there was cooperation at the operational and executive strata but 'the weight of submissions painted a picture of animosity and mistrust between FRNSW and the RFS in many districts and 
at the middle management level' (Keelty 2018, p.18). The review also highlighted that call-and-dispatch arrangements between a 000 caller, RFS and the RFS were flawed and in need of urgent reform. Aspects of this lesson are aligned to the executive strata (by prioritising and funding resources for improving the system) and the middle management strata (by implementing the recommendations to improve the system).

\section{Extracting themes}

Once the full set of lessons were extracted, they were grouped into themes (Table 4). A theme included extracted lessons that were identified in 3 or more reviews. These themes included the need to update legislation, procedures and documents so that the emergency services organisations can adapt to different bushfire conditions, environments and circumstances. There was also emphasis on control and coordination within and between emergency services organisations. This control and coordination included role clarification and improving community education and bushfire warnings processes. Several of the themes are directly relevant to the national themes detailed in the Lessons Management Handbook (Australian Institute for Disaster Resilience 2019). Each theme was then mapped against the relevant emergency management phase and the relevant (indicative) strata (Table 5).

Table 4: Extracted themes.

\begin{tabular}{|c|c|c|c|c|c|}
\hline \multirow[b]{2}{*}{ Lesson category } & \multirow[b]{2}{*}{ Specific lesson } & \multicolumn{4}{|c|}{ Reviews of Australian bushfires } \\
\hline & & $\begin{array}{c}\text { Ash } \\
\text { Wednesday } \\
1983\end{array}$ & $\begin{array}{c}\text { Victorian } \\
\text { Bushfire } \\
\text { Review } 2009\end{array}$ & $\begin{array}{l}\text { Margaret } \\
\text { River } 2011\end{array}$ & $\begin{array}{l}\text { Bega Valley } \\
\quad 2018\end{array}$ \\
\hline \multirow[t]{2}{*}{ Relevant fire factor } & Weather conditions & yes & yes & yes & no \\
\hline & Fuel load & yes & yes & yes & no \\
\hline \multirow{6}{*}{$\begin{array}{l}\text { Recommends } \\
\text { updating legislation } \\
\text { and procedures }\end{array}$} & $\begin{array}{l}\text { Legislation and/or policies are out-of-date } \\
\text { and/or difficult to implement }\end{array}$ & yes & yes & yes & yes \\
\hline & Increase the number of prescribed burns & yes & yes & yes & no \\
\hline & $\begin{array}{l}\text { Change building codes, planning and/or zoning } \\
\text { to reflect bushfire risk }\end{array}$ & yes & yes & yes & no \\
\hline & $\begin{array}{l}\text { Update documents (i.e. disaster plans and } \\
\text { incident action plans) }\end{array}$ & yes & yes & yes & no \\
\hline & $\begin{array}{l}\text { Problems shifting between non-disaster and } \\
\text { disaster roles }\end{array}$ & yes & yes & yes & no \\
\hline & Inconsistent processes & yes & yes & yes & yes \\
\hline \multirow[t]{2}{*}{ Coordination } & Liaison between agencies needs to improve & yes & yes & yes & yes \\
\hline & Need for role clarification & yes & yes & no & yes \\
\hline Communication & $\begin{array}{l}\text { Warnings/information system needs to } \\
\text { improve }\end{array}$ & yes & yes & yes & no \\
\hline \multirow{2}{*}{$\begin{array}{l}\text { Resources, } \\
\text { equipment and } \\
\text { systems }\end{array}$} & Importance of volunteers and local knowledge & yes & yes & yes & yes \\
\hline & Communications and/or IT equipment & yes & yes & no & yes \\
\hline Future threat & Future threat from bushfires & yes & yes & yes & yes \\
\hline
\end{tabular}


M RESEARCH

Table 5: Sample of extracted themes mapping against the emergency management phase and indicative strata.

\begin{tabular}{llll} 
Lesson category & Specific lesson & Phase & Indicative strata \\
\hline $\begin{array}{lll}\text { Recommends updating } \\
\text { legislation, procedures }\end{array}$ & $\begin{array}{l}\text { Increase the } \\
\text { number of } \\
\text { prescribed burns }\end{array}$ & Prevention & $\begin{array}{l}\text { Executive: } \text { Responsible for updating legislation, procedures and } \\
\text { the overarching suite of documents; sets priorities and policies for } \\
\end{array}$ \\
& & $\begin{array}{l}\text { prescribed burns; setting organisational culture (ongoing emphasis } \\
\text { on officer safety). }\end{array}$
\end{tabular}

Middle management: Responsible for the operational risks for each prescribed burn; applying rating/prioritisation system consistently; allocating resources

Operational: Conduct additional prescribed burns; using equipment; following procedures.

\begin{tabular}{|c|c|c|c|}
\hline Communication & $\begin{array}{l}\text { Warnings/ } \\
\text { information } \\
\text { system needs to } \\
\text { improve }\end{array}$ & $\begin{array}{l}\text { Prepare and } \\
\text { Respond }\end{array}$ & $\begin{array}{l}\text { Executive: Prioritise standardising IT systems; fund updated IT and } \\
\text { communication systems. } \\
\text { Middle management: Standardise (as much as possible) briefing } \\
\text { processes and information flows to/from the tactical teams; } \\
\text { regional level middle management to develop region-specific } \\
\text { advice for the public. } \\
\text { Operational: Provide specific advice to community groups using } \\
\text { different formats/platforms. }\end{array}$ \\
\hline Coordination & $\begin{array}{l}\text { Liaison between } \\
\text { agencies needs to } \\
\text { improve }\end{array}$ & $\begin{array}{l}\text { Plan, prepare, } \\
\text { respond, } \\
\text { recovery }\end{array}$ & $\begin{array}{l}\text { Executive: Responsible for establishing an organisational culture } \\
\text { that focuses on liaison; creating and enforcing standards. } \\
\text { Middle management: Responsible for liaison at the middle } \\
\text { management level and ensuring operational-level liaison occurs; } \\
\text { role clarification at team level. } \\
\text { Operational: Liaison at the operational level. }\end{array}$ \\
\hline $\begin{array}{l}\text { Resources, equipment } \\
\text { and systems }\end{array}$ & $\begin{array}{l}\text { Importance of } \\
\text { volunteers and } \\
\text { local knowledge }\end{array}$ & $\begin{array}{l}\text { Plan, prepare, } \\
\text { respond, } \\
\text { recovery }\end{array}$ & $\begin{array}{l}\text { Middle management: Problems in communication and information } \\
\text { sharing between the government agency and volunteer brigades. }\end{array}$ \\
\hline
\end{tabular}

\section{Do emergency services lessons occur across the stratum?}

Findings from this research supported the proposition made in the research question by finding that lessons learnt can be aligned to specific organisational strata. Findings can be supported through the need for specific stratum learning in legislation, communications, coordination and resourcing. For example, the 2009 Victorian bushfire review recommended:

...the Country Fire Authority and the Department of Sustainability and Environment standardise their operating systems and information and communications technologies with the aim of achieving greater efficiency and interoperability between agencies.

(Teague et al. 2010, p.28).

This study also found that at the executive strata there is a responsibility to establish an organisational culture that focuses on intra- and inter-departmental liaison. Whereas, at the middle management strata, the indicative focus is towards standardising processes. Finally, at the operational strata, liaison needs to be enabled and supported. Further research could consider whether there are specific barriers at different operational strata that impede the lessons-learnt process in emergency services organisations. Improving lessons-learnt processes could have flow-on implications for communities through better responses to emergency incidents and for government through improved use of resources.

\section{Limitations}

A limitation of this study was the difficulty in comparing the selected incidents using only the external reviews as sources. The reviews ranged in scale, with the 1983 and 2009 reviews focusing on all 4 phases of the emergency management cycle, while the other 2 reviews were narrower in scope. Apart from the 2 Victorian incidents, the other incidents occurred in different Australian states and involved different jurisdictions and different emergency services organisations. Therefore, it was difficult to assess whether a 2011 review into prescribed bushfires getting out of control in Western Australia should have learnt from a 1983 review into bushfires in Victoria. 


\section{Conclusion}

This study supported the proposition that emergency services organisations need to continually improve and that some learning between significant bushfire incidents occurs. However, reviews undertaken following significant bushfire events still indicate that further work is required. Furthermore, that lessons learnt are implicitly aligned towards specific stratum. Therefore, to assist the lessons-learnt process would be to align lessons to specific organisational strata, as this provides clearer advice to the organisations about who should be responsible for learning from each identified lesson.

\section{References}

Aubry M \& Lavoie-Tremblay M 2018, Rethinking organizational design for managing multiple projects, International Journal of Project Management, vol. 36, no. 3, pp.12-26.

Australian Institute for Disaster Resilience 2019, Lessons Management Handbook (2nd ed). At: https://knowledge.aidr.org. au/resources/lessons-management-handbook/ [19 October 2020].

Australian Law Reform Commission 2010, Royal Commissions and official inquiries. At: www.alrc.gov.au/inquiry/royal-commissionsand-official-inquiries/ [1 March 2020].

Benoot C, Hannes K \& Bilsen J 2016, The use of purposeful sampling in a qualitative evidence synthesis: A worked example on sexual adjustment to a cancer trajectory, BMC Medical Research Methodology, vol. 16, no. 1, pp.16-21. doi:10.1186/s12874-0160114-6

Boin A \& t'Hart P 2010, Organising for Effective Emergency Management: Lessons from Research, Australian Journal of Public Administration, vol. 69, no. 4, pp.357-371. doi:10.1111/j.14678500.2010.00694.x

Braun V \& Clarke V 2006, Using thematic analysis in psychology, Qualitative Research in Psychology, vol. 3, no. 2, pp.77-101.

Cameron PA, Mitra B, Fitzgerald M, Scheinkestel CD, Stripp A, Batey C, Niggemeyer L, Truesdale M, Holman P, Mehra R, Wasiak J \& Cleland H 2009, Black Saturday: the immediate impact of the February 2009 bushfires in Victoria, Australia, Medical Journal of Australia, vol. 191, pp.11-16. doi:10.5694/j.1326-5377.2009. tb02666.x

Cole L, Dovers S, Gough M \& Eburn M 2018, Can major postevent inquiries and reviews contribute to lessons management? Australian Journal of Emergency Management, vol. 33, no. 2, pp.34-39.

Craddock K 2009, Requisite Organization Annotated Bibliography: An Annotated Research Bibliography on Elliott Jaques (5th ed): Part 1. At: http://dmcodyssey.org/wp-content/uploads/2013/09/ RO-Intro.pdf [12 February 2020].

Creswell JW \& Plano Clark VL 2018, Designing and conducting mixed methods research, 3rd edn, SAGE Publications Inc, Thousand Oaks, California.
CSIRO \& Bureau of Meteorology 2018, State of the Climate 2018, Bureau of Meteorology. At: www.bom.gov.au/state-of-theclimate/State-of-the-Climate-2018.pdf [14 March 2020].

Deverell E 2009, Crises as Learning Triggers: Exploring a Conceptual Framework of Crisis-Induced Learning, Journal of Contingencies and Crisis Management, vol. 17, no. 3, pp.179-188.

Donahue A \& Tuohy R 2006, Lessons We Don't Learn: A Study of the Lessons of Disasters, Why We Repeat Them, and How We Can Learn Them, Homeland Security Affairs. At: www.hsaj.org/ articles/167 [21 October 2020].

Duffield S \& Whitty SJ 2015, Developing a systemic lessons learned knowledge model for organisational learning through projects, International Journal of Project Management, vol. 33, no. 2, pp.311-324.

Dufty N 2013, Evaluating emergency management after an event: gaps and suggestions, Australian Journal of Emergency Management, vol. 28, no. 4, pp.15-19.

Eburn M \& Dovers S 2015, Learning Lessons from Disasters: Alternatives to Royal Commissions and Other Quasi-Judicial Inquiries, Australian Journal of Public Administration, vol. 74, no. 4, pp.495-508. doi:10.1111/1467-8500.12115

Ferguson E 2010, A Review of the Ability of the Department of Environment and Conservation Western Australia to Manage Major Fires. At: https://library.dbca.wa.gov.au/static/ FullTextFiles/628453.pdf.

Garvin DA, Edmondson AC \& Gino F 2008, Tool Kit: Is Yours a Learning Organization?, Harvard Business Review. At: https://hbr. org/2008/03/is-yours-a-learning-organization [20 October 2020 ].

Glassey S 2015, Opinion: Preventing 'lessons lost': is evidencebased dynamic doctrine the answer? Australian Journal of Emergency Management, vol. 30, no.3, pp.11-14.

Howes M, Tangney P, Reis K, Grant-Smith D, Heazle M, Bosomworth K \& Burton P 2015, Towards networked governance: improving interagency communication and collaboration for disaster risk management and climate change adaptation in Australia, Journal of Environmental Planning and Management, vol. 58, no. 5, pp.757-776.

Jackson LM 2016, The influence of organisational culture on learning lessons: implementing a lessons management life cycle, Australian Journal of Emergency Management, vol. 31, no. 1, pp.18-23.

Jaques E 1990, In Praise of Hierarchy, Harvard Business Review, vol. 1990, no. January-February. At: https://hbr.org/1990/01/inpraise-of-hierarchy [14 March 2020].

Jaques E 1996, Requisite Organization: A Total System for Effective Managerial Organization and Managerial Leadership for the 21st Century, 2nd edn, Carson Hall \& Co, Arlington, Virginia.

Jaques E 2016, Requisite Organization: A Total System for Effective Managerial Organization and Managerial Leadership for the 21st Century, Revised 2nd edn, Routledge, London. 
Jaques E 2002, The Life and Behavior of Living Organisms A General Theory, Praeger Publishers, Westport.

Keelty MJ 2012, Appreciating the Risk: Report of the Special Inquiry into the November 2011 Margaret River Bushfire, Western Australia Public Sector Commission. At: https://publicsector. wa.gov.au/sites/default/files/documents/inquiry_-_margaret_ river_bushfire_-_report_-_appreciating_the_risk_with_ annexures.pdf.

Keelty MJ 2018, Bega Valley Fires Independent Review, Resilience NSW, www.emergency.nsw.gov.au/Documents/publications/ Bega-Valley-Fire-Independent-Review.PDF.

Leonard HB \& Howitt AM 2010, Organising Response to Extreme Emergencies: The Victorian Bushfires of 2009, Australian Journal of Public Administration, vol. 69, pp.372-386.

Leung L 2015, Validity, reliability, and generalizability in qualitative research, Journal of Family Medicine and Primary Care, vol. 4, no. 3, pp.324-327. doi:10.4103/2249-4863.161306

McAneney J, Chen K \& Pitman A 2009, 100-years of Australian bushfire property losses: Is the risk significant and is it increasing?' Journal of Environmental Management, vol. 90, no. 8, pp.2819-22.

McCaw WL 2013, Managing forest fuels using prescribed fire - A perspective from southern Australia, Forest Ecology and Management, vol. 294, pp.217-224.

Miller SI, Carter W \& Stephens RG 1984, Report of the bushfire review committee on bushfire disaster preparedness and response in Victoria, Australia, following the Ash Wednesday Fires 16 February 1983, State Library of Victoria. At: http://search.s/v.vic. gov.au/permalink/f/1cl35st/SLV_VOYAGER74639.

Owen C, Brooks B, Curnin S \& Bearman C 2018, Enhancing Learning in Emergency Services Organisational Work, Australian Journal of Public Administration, vol. 77, no. 4, pp.715-728. doi:10.1111/1467-8500.12309

Rowe SF \& Sikes S 2006, Lessons learned: taking it to the next level' $P M I^{\circledR}$ Global Congress 2006 North America, Seattle. At: www.pmi.org/learning/library/lessons-learned-next-levelcommunicating-7991.

Stuart H \& Thomason M 2018, Case study: lessons management capability in emergency management and beyond, Australian Journal of Emergency Management, vol. 33, no. 2, pp.16-17.

Teague B, McLeod R \& Pascoe S 2010, 2009 Victorian Bushfires Royal Commission Final Report: Summary, Victoria Government. At: http://royalcommission.vic.gov.au/finaldocuments/summary/ PF/VBRC_Summary_PF.pdf.

Valent P 1984, The Ash Wednesday bushfires in Victoria, Medical Journal of Australia, vol. 141, pp.291-300.

Whitmer DE, LaGoy MR \& Sims VK 2018, Understanding emergency response: lessons learned from the helping literature, International Journal of Emergency Management, vol. 14, no. 1, pp.23-39. doi:10.1504/IJEM.2018.089187
Winkworth G, Healy C, Woodward M \& Camilleri P 2009, Community capacity building: Learning from the 2003 Canberra bushfires, Australian Journal of Emergency Management, vol. 24, no. 2, pp.5-12.

\section{About the authors}

Jennifer Medbury lectures in intelligence and terrorism studies at Edith Cowan University. She has over 11 years' experience as an intelligence analyst and senior intelligence analyst with the Australian Defence Intelligence Organisation and the Western Australia Police Force.

Dr David Brooks is the Associate Professor in Security Science at Edith Cowan University. His interests are in the security science body of knowledge, security system design and evaluation.

Michael Coole is a senior lecturer and researcher at Edith Cowan University. He has 25 years' experience in the security and emergency management fields and has worked in the Australian Defence Force, Western Australia's Department of Corrective Services and as a private security consultant. 